\title{
Orthodeoxia and its implications on awake-proning in COVID-19 pneumonia
}

\author{
Lorenzo Giosa', Didier Payen², Mattia Busana ${ }^{3}$, Alessio Mattei ${ }^{4}$, Luca Brazzi ${ }^{1,5}$ and Pietro Caironi $i^{6,7^{*}}$ (i)
}

Dear editor,

When caring for patients with respiratory failure, decubitus is a daily challenge. In the acute-respiratorydistress-syndrome (ARDS), seated and prone position increase lung volume and, consequently, oxygenation [1]. In COVID-19, however, gas-exchange is often independent of lung volume [2], and rather affected by perfusion dysregulation [3]. In similar settings, like the hepatopulmonary syndrome (HPS), recumbency may revert hypoxemia [4]: this phenomenon goes under the name of orthodeoxia, and here we hypothesize its presence in COVID-19. Clinical implications might be relevant: recumbency is the state of lying horizontally at $0^{\circ}$, supine or prone. Awake-proning has already proven beneficial on oxygenation in spontaneously breathing patients with early COVID-19 pneumonia [5]. However, as a heritage from ARDS, these patients are usually seated or semirecumbent, thereby the ventral decubitus is rarely compared to supination at $0^{\circ}$ : the finding of orthodeoxia may lead to partially ascribe the oxygenation benefits of awake-proning [5] to recumbency rather than to the ventral decubitus itself.

At the University Hospital of Turin (Italy), following ethical approval (Città della Salute e della Scienza 00581/2020), we studied non-sedated COVID-19 patients requiring early $(<7$ days $)$ respiratory support with helmet continuous positive airway pressure (HCPAP) or high flow nasal cannula (HFNC). Concomitant pulmonary embolism and/or bacterial pneumonia

*Correspondence: pietro.caironi@unito.it

${ }^{6}$ Department of Anesthesia and Critical Care, AOU S. Luigi Gonzaga, Turin, Italy

Full list of author information is available at the end of the article represented exclusion criteria. After signing a written informed consent, participants were assigned to a random sequence of seated (trunk elevation $>60^{\circ}$, legs down at $45^{\circ}$ ), supine and prone position (both recumbent at $0^{\circ}$ ) during constant respiratory support as set by the attending physician. Blood gases, respiratory rate, dyspnea and discomfort, basic hemodynamics and, when available, cardiac output $\left(\mathrm{CNAP}^{\circledR}, \mathrm{CNSystems}\right.$ Medizintechnik $\mathrm{GmbH}$ ) were assessed twenty minutes from each decubitus. A threshold of $\geq 20 \%$ increase in $\mathrm{PaO}_{2}$ defined supine responders (supine vs seated) and prone responders (prone vs supine). The primary outcome was the frequency of orthodeoxia (supine responders). R-3.5.2 was used for statistical computing: Wilcoxon test for median comparisons, Fisher exact test for contingency tables, two-sided $p<0.05$ for significance.

After excluding 28 eligible patients ( 21 for pulmonary embolism, 7 for superimposed bacterial pneumonia), 30 were recruited in two months (February-March 2021); two declined to participate. Results and baseline characteristics of the 28 enrolled patients are summarized in Table 1. Orthodeoxia was detected in $14(50 \%)$ of them, with a far higher $\mathrm{PaO}_{2}$ increase (31 [26-44] $\mathrm{mmHg}$ ), than what normally required to define it $(4 \mathrm{mmHg})$ [3]. Neither the starting decubitus $(p=0.33)$, nor the type of respiratory support (HCPAP or HFNC, $p=1.00$ ) affected this result, and the stability of cardiac output from seated to supine minimizes the possibility that macro-hemodynamics played any significant role. A decrease in respiratory rate in the absence of dyspnea and discomfort was also associated with supination in our population. During proning, patients with and without orthodeoxia behaved similarly: respectively, $6(46 \%)$ and $5(36 \%)$ were prone responders $\left(p=0.70\right.$, median $\mathrm{PaO}_{2}$ increase original author(s) and the source, provide a link to the Creative Commons licence, and indicate if changes were made. The images or other third party material in this article are included in the article's Creative Commons licence, unless indicated otherwise in a credit line to the material. If material is not included in the article's Creative Commons licence and your intended use is not permitted by statutory regulation or exceeds the permitted use, you will need to obtain permission directly from the copyright holder. To view a copy of this licence, visit http://creativecommons.org/licenses/by/4.0/. The Creative Commons Public Domain Dedication waiver (http://creativeco mmons.org/publicdomain/zero/1.0/) applies to the data made available in this article, unless otherwise stated in a credit line to the data. 
Table 1 Characteristics of Patients and Main Results

\begin{tabular}{|c|c|c|c|c|c|c|}
\hline & & \multicolumn{2}{|c|}{ SUPINE RESPONDERS } & \multicolumn{2}{|c|}{ SUPINE NON-RESPONDERS } & \\
\hline \multicolumn{7}{|c|}{ Baseline characteristics } \\
\hline \multicolumn{2}{|l|}{ No (\%) } & \multicolumn{2}{|l|}{$14(50)$} & \multicolumn{2}{|l|}{$14(50)$} & \\
\hline \multicolumn{2}{|l|}{ Age, median (IQR) } & \multicolumn{2}{|l|}{$66(56-72)$} & \multicolumn{2}{|l|}{$66(57-69)$} & \\
\hline \multicolumn{7}{|l|}{ Sex, No (\%) } \\
\hline \multicolumn{2}{|l|}{ Women } & \multicolumn{2}{|l|}{$1(7.1)$} & \multicolumn{2}{|l|}{$5(35.7)$} & \\
\hline \multicolumn{2}{|l|}{ Men } & \multicolumn{2}{|l|}{$13(92.9)$} & \multicolumn{2}{|l|}{$9(64.3)$} & \\
\hline \multicolumn{2}{|l|}{ BMI, median (IQR) } & \multicolumn{2}{|l|}{$27.5(24.2-30.0)$} & \multicolumn{2}{|c|}{$28.3(27.5-31.1)$} & \\
\hline \multicolumn{2}{|l|}{ Current smokers, No (\%) } & \multicolumn{2}{|l|}{$1(7)$} & \multicolumn{2}{|l|}{$0(0)$} & \\
\hline \multicolumn{2}{|c|}{ Arterial hypertension, No (\%) } & \multicolumn{2}{|l|}{$7(50)$} & \multicolumn{2}{|l|}{$9(64)$} & \\
\hline \multicolumn{2}{|c|}{ Type 2 Diabetes Mellitus, No (\%) } & \multicolumn{2}{|l|}{$1(7)$} & $4(29)$ & & \\
\hline SOFA score, median (IC & QR) & $3(3-3)$ & & $3(2-3)$ & & \\
\hline Disease course, median & $n(I Q R)$ & & & & & \\
\hline Days from diagnosis of & f infection & $11.5(8-14)$ & & $9.5(8-12)$ & & \\
\hline Days from hospital adr & Imission & $3.5(2-7)$ & & $3.5(2-6)$ & & \\
\hline Days from respiratory s & support & $2.5(1-5)$ & & $2(1-4)$ & & \\
\hline Ventilatory settings & & & & & & \\
\hline HCPAP, No (\%) & & $11(79)$ & & $11(79)$ & & \\
\hline HFNC, No (\%) & & $3(21)$ & & $3(21)$ & & \\
\hline $\mathrm{FiO}_{2}$, median (IQR) & & $0.5(0.5-0.6)$ & & $0.5(0.5-0.5)$ & & \\
\hline PEEP (if HCPAP), media & an (IQR) & $10(10-12)$ & & $10(10-12)$ & & \\
\hline Flow (if HFNC), median & in $(I Q R)$ & $40(35-40)$ & & $35(35-40)$ & & \\
\hline Protocol & Seated & Supine & Prone & Seated & Supine & Prone \\
\hline $\begin{array}{l}\text { Starting decubitus, } \\
\text { no (\%) }\end{array}$ & $2(14)$ & $6(43)$ & $6(43)$ & $4(29)$ & $5(36)$ & $5(36)$ \\
\hline $\begin{array}{l}\text { Respiratory variables, } \\
\text { median (IQR) }\end{array}$ & & & & & & \\
\hline $\mathrm{PaO}_{2}, \mathrm{mmHg}$ & $82.2(73.2-101)$ & $120(108-149)^{*}$ & $139(108-184)^{*}$ & $96(67-117)$ & $92(74-120)$ & $102(68.5-125)^{*}$ \\
\hline $\mathrm{PaO}_{2} / \mathrm{FiO}_{2}$ ratio & $152(133-177)$ & $224(186-248)^{*}$ & $278(198-336)^{*}$ & $192(160-224)$ & $186(165-230)$ & $204(150-246)$ \\
\hline $\mathrm{PaCO}_{2}, \mathrm{mmHg}$ & $38(35.9-39)$ & $39.1(38-43)^{*}$ & $37.8(37-41)^{*}$ & $38.3(34.1-40)$ & $40.5(35.8-42)^{*}$ & $39.8(36-41)$ \\
\hline Arterial pH & $7.45(7.44-7.46)$ & $7.43(7.43-7.45)^{*}$ & $7.44(7.44-7.46)$ & $7.46(7.44-7.47)$ & $7.45(7.42-7.47)^{*}$ & $7.44(7.43-7.46)$ \\
\hline Respiratory rate, bpm & $19(17-22)$ & $17(15-18)^{*}$ & $19(16-23)^{*}$ & $21.5(18-24)$ & $19(16-22)^{*}$ & $18.5(16-21)$ \\
\hline Subjective variables & & & & & & \\
\hline $\begin{array}{l}\text { Borg dyspnea scale, } \\
\text { median (IQR) }\end{array}$ & $0(0-0)$ & $0(0-0)$ & $0(0-0)$ & $0(0-0)$ & $0(0-0)$ & $0(0-1)$ \\
\hline Discomfort, no (\%) & $2(14.3)$ & $1(7.1)$ & $8(57.1)^{*}$ & $0(0)$ & $0(0)$ & $5(35.7)^{*}$ \\
\hline $\begin{array}{l}\text { Hemodynamics, } \\
\text { median (IQR) }\end{array}$ & & & & & & \\
\hline $\begin{array}{l}\text { Cardiac index, L/min/ } \\
\mathrm{m}^{2 \mathrm{a}}\end{array}$ & $3(3-3.2)$ & $3.1(3-3.3)$ & $3.3(3.3-3.5)^{*}$ & $2.8(2.5-3.5)$ & $2.9(2.4-3.1)$ & $3.1(3-3.4)^{*}$ \\
\hline $\begin{array}{l}\text { Stroke volume index, } \\
\mathrm{mL} / \mathrm{m}^{2 a}\end{array}$ & $41(39-42)$ & $47(38-48)^{*}$ & $46(40-52)$ & $39(33-45)$ & $50(37-55)^{*}$ & $40(37-51)$ \\
\hline Pulse pressure, $\mathrm{mmHg}$ & $951(42-58)$ & $55(47-60)^{*}$ & $54(48-70)$ & $55(46-78)$ & $69(53-90)^{*}$ & $71(56-81)$ \\
\hline Heart rate, bpm & $70(69-77)$ & $64(60-71)^{*}$ & $68(60-77)^{*}$ & $75(67-86)$ & $70(60-76)^{*}$ & $76(69-82)^{*}$ \\
\hline
\end{tabular}

$\mathrm{IQR}$, interquartile range; $\mathrm{BMI}$, body mass index (weight in kilograms divided by the square of the height in meters); SOFA, sequential organ failure assessment; $\mathrm{HCPAP}$, helmet continuous positive airway pressure; $\mathrm{HFNC}$, high flow nasal cannula; $\mathrm{FiO}_{2}$, fraction of inspired oxygen; $\mathrm{PEEP}$, positive end expiratory pressure; $\mathrm{PaO}{ }_{2}$, partial pressure of oxygen; $\mathrm{mmHg}$, millimeters of mercury; $\mathrm{PaCO}_{2}$, partial pressure of carbon dioxide; bpm, breaths (or beats) per minute

${ }^{a}$ Data available from 12 patients (5 supine responders and 7 supine non-responders) equipped with non-invasive advanced hemodynamic monitoring (CNAP ${ }^{\circledR}$ ). Note that changes in stroke volume are paralleled by changes in pulse pressure (its surrogate) confirming the trend of cardiac output even in patients without advanced hemodynamic monitoring

* Significantly different $(p<0.05)$ with respect to the preceding decubitus in the table 


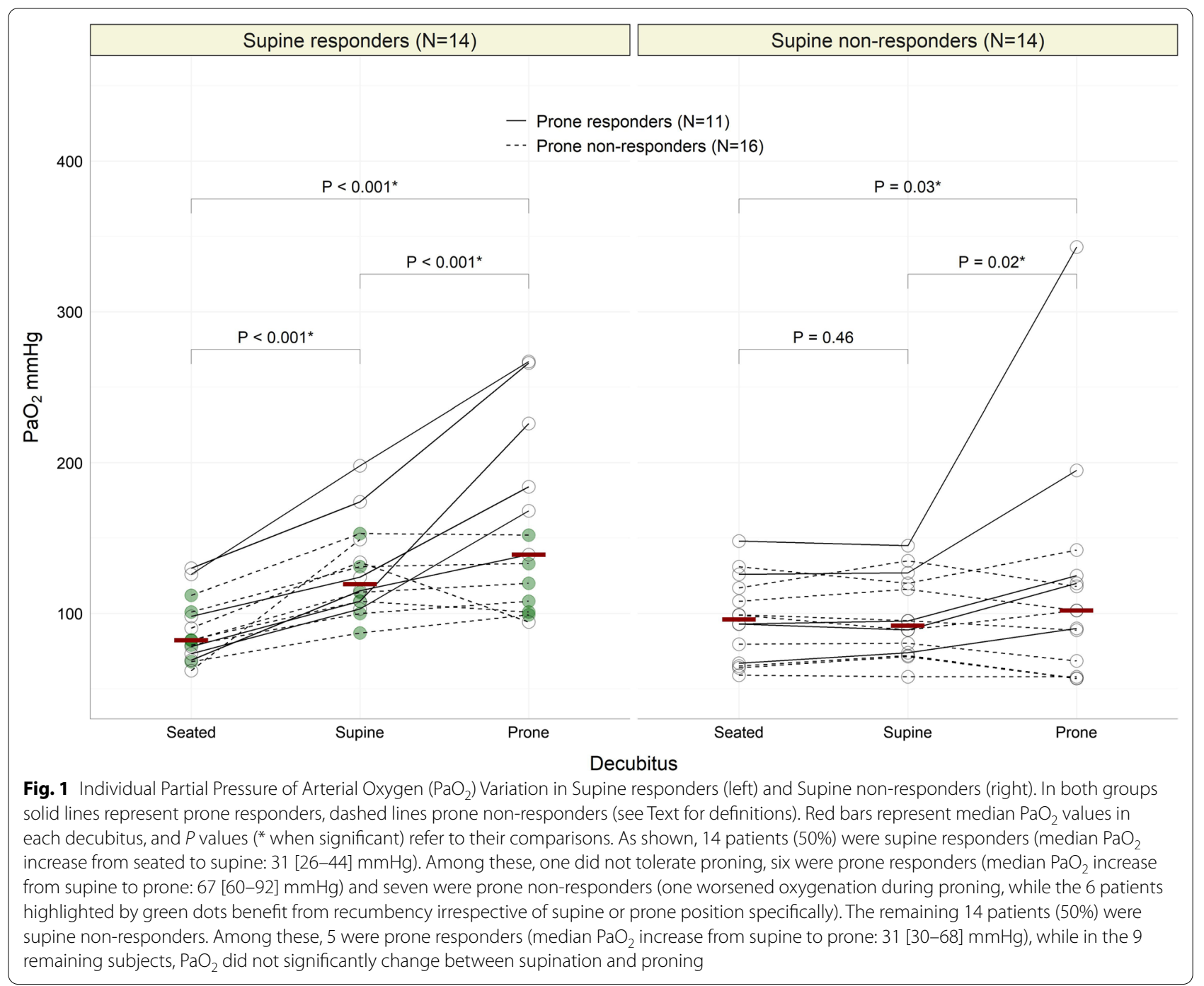

$65[30-92] \mathrm{mmHg})$. This suggests that orthodeoxia cannot anticipate the response to proning, likely because of the unpredictable balance between perfusion redistribution and parenchymal reaeration in the ventral position [6]. However, the finding of orthodeoxia avoided overestimating the benefits of awake-pronation in 6 patients (22\%) whose oxygenation improvement was due to lying recumbent at $0^{\circ}$, irrespective of prone or supine specifically (Fig. 1, green dots). Considering that the ventral decubitus was associated with discomfort, higher respiratory and heart rate, the decision to prone would be questionable in these patients.

In conclusion, orthodeoxia appears a common clinical feature of early COVID-19 pneumonia. This novel finding contributes to further distinguishing COVID-19 from other causes of ARDS [1, 2, 6], while reinforcing its advocated similarity with HPS [3, 4]. Additionally, detecting orthodeoxia may help avoid awake-pronation when oxygenation simply benefits from recumbency: in a pandemic scenario, this possibly relevant clinical implication would deserve confirmation by larger studies.

\section{Acknowledgements}

None declared.

\section{Authors' contributions}

$L G, D P, M B$ and $P C$ conceptualised the study. $L G$ and $A M$ collected the data $L G, M B$ and $P C$ analysed the data. $L G$ drafted the manuscript and $P C, M B$, $D P$ and $L B$ revised it. All authors read and approved the final version of the manuscript.

\section{Funding}

None declared.

\section{Availability of data and materials}

The dataset used and analysed for this study is available from the corresponding author upon reasonable request. 


\section{Declarations}

Ethics approval and consent for participation

This study was approved by Città della Salute e della Scienza (00581/2020)

University Hospitals' Research Ethics Board (Turin, Italy). Every patient

approved to participate by signing a written informed consent.

\section{Patient consent for publication}

Acquired (written and signed by each participant).

\section{Competing interests}

The authors declare that they have no competing interests.

\section{Author details}

${ }^{1}$ Department of Surgical Sciences, University of Turin, Turin, Italy. ${ }^{2}$ University of Paris, 7, Denis Diderot, Paris, France. ${ }^{3}$ Department of Anesthesiology, University Medical Center Göttingen, Göttingen, Germany. ${ }^{4}$ Department of Cardio-Thoracic Diseases, 'Città della Salute e della Scienza' University Hospital, Turin, Italy. ${ }^{5}$ Department of Anaesthesia, Intensive Care and Emergency, 'Città della salute e della Scienza' University Hospital, Turin, Italy. ${ }^{6}$ Department of Anesthesia and Critical Care, AOU S. Luigi Gonzaga, Turin, Italy. ${ }^{7}$ Department of Oncology, University of Turin, Turin, Italy.

Received: 4 December 2021 Accepted: 6 December 2021

Published online: 16 December 2021

\section{References}

1. Mezidi M, Guérin C. Effects of patient positioning on respiratory mechanics in mechanically ventilated ICU patients. Ann Transl Med. 2018;6(19):384.

2. Coppola S, Chiumello D, Busana M, Giola E, Palermo P, Pozzi T, et al. Role of total lung stress on the progression of early COVID-19 pneumonia. Intensive Care Med. 2021:47:1130-9.

3. Reynolds AS, Lee AG, Renz J, DeSantis K, Liang J, Powell CA, Ventetuolo CE, Poor HD. Pulmonary vascular dilatation detected by automated transcranial Doppler in COVID-19 pneumonia. Am J Respir Crit Care Med. 2020;202:1037-9.

4. Gómez FP, Martinez-Palli G, Barberà JA, Roca J, Navasa M, RodriguezRoisin R. Gas exchange mechanism of orthodeoxia in hepatopulmonary syndrome. Hepatology. 2004;40(3):660-6.

5. Coppo A, Bellani G, Winterton D, Di Pierro M, Soria A, Faverio P, et al. Feasibility and physiological effects of prone positioning in non-intubated patients with acute respiratory failure due to COVID-19 (PRON-COVID): a prospective cohort study. Lancet Respir Med. 2020;8(8):765-74.

6. Rossi S, Palumbo MM, Sverzellati N, Busana M, Malchiodi L, Bresciani P, et al. Mechanisms of oxygenation responses to proning and recruitment in COVID-19 pneumonia. Intensive Care Med. 2021. https://doi.org/10. 1007/s00134-021-06562-4.

\section{Publisher's Note}

Springer Nature remains neutral with regard to jurisdictional claims in published maps and institutional affiliations.

Ready to submit your research? Choose BMC and benefit from:

- fast, convenient online submission

- thorough peer review by experienced researchers in your field

- rapid publication on acceptance

- support for research data, including large and complex data types

- gold Open Access which fosters wider collaboration and increased citations

- maximum visibility for your research: over $100 \mathrm{M}$ website views per year

At BMC, research is always in progress.

Learn more biomedcentral.com/submissions 